\title{
Zirconium Zr 89 Panitumumab
}

National Cancer Institute

\section{Source}

National Cancer Institute. Zirconium Zr 89 Panitumumab. NCI Thesaurus. Code C156043.

A radioimmunoconjug ate composed of panitumumab, a human immunog lobulin G2 (IgG2) monoclonal antibody directed against the epidermal growth factor receptor (EGFR; HER1; ErbB1), labeled with the radioisotope zirconium Zr 89, with potential use as an imaging agent upon positron emission tomography (PET). Upon administration of zirconium $\mathrm{Zr} 89$ panitumumab, the antibody moiety targ ets and binds to the extracellular domain of EGFR on tumor cells. Upon PET imaging, EGFR-expressing tumor cells can be visualized and assessed. This allows quantification of EGFR-expressing tumor cells and may allow selection of patients that would respond to panitumumab therapy. EGFR, a receptor tyrosine kinase overexpressed on the cell surfaces of many tumor cell types, plays a key role in tumor cell proliferation. 